\title{
Chemical analyses of flowers and leaves for nutritional diagnoses of coffee trees
}

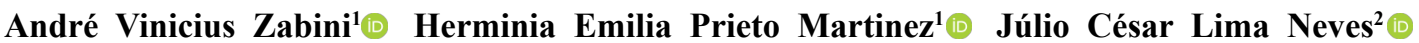 \\ Cosme Damião Cruz ${ }^{1}$ (D) Samuel Vasconcelos Valadares ${ }^{2 *}$ (I)
}

${ }^{1}$ Departamento de Agronomia, Universidade Federal de Viçosa (UFV), Viçosa, MG, Brasil

${ }^{2}$ Departamento de Solos, Universidade Federal de Viçosa (UFV), 36570-900, Viçosa, MG, Brasil. E-mail: samuel.valadares@ufv.br. ${ }^{*}$ Corresponding author.

ABSTRACT: The chemical analysis of flowers has been studied for some crops. In coffee trees, the flower tissue analysis could anticipate the nutritional diagnosis. This study aimed to: (i) compare the mineral composition of coffee flowers and leaves; and to (ii) generate reference values for nutritional diagnosis of coffee trees, based on flower and leaf analysis. Nutrient content of flowers and leaves and coffee productivity were evaluated in 26 commercial farms located in Manhuaçu, MG, Brazil throughout three years. The critical nutrient content range in flowers are respectively: $2.78-3.17,0.23-0.28,2.80-3.12,0.30-0.37,0.24-0.30,0.15-0.18 \mathrm{dag} \mathrm{kg}^{-1} \mathrm{of} \mathrm{N}, \mathrm{P}, \mathrm{K}, \mathrm{Ca}, \mathrm{Mg}$, and $\mathrm{S} ;$ and $17-21,12$ $-18,52-80,26-43$, and $28-48 \mathrm{mg} \mathrm{kg}^{-1}$ of $\mathrm{Zn}, \mathrm{Cu}, \mathrm{Mn}, \mathrm{Fe}$, and B. For leaves, the critical nutrient ranges are respectively: $2.63-2.86,0.13$ - 0.14, 2.13-2.33, 1.04-1.22, 0.27-0.33, 0.15-0.18 dag $\mathrm{kg}^{-1}$ of N, P, K, Ca, Mg, and S; and 9-14, 15-23, 80-115, 99-148, and 31-37 $m g \mathrm{~kg}^{-1}$ of $\mathrm{Zn}, \mathrm{Cu}, \mathrm{Mn}, \mathrm{Fe}$, and B. The nutritional diagnosis of coffee trees for $\mathrm{N}, \mathrm{P}, \mathrm{Ca}, \mathrm{Fe}, \mathrm{Cu}$, and Mn can be anticipated using flower analysis. Key words: Coffea arabica L., leaf analysis, flower analysis, coffee tree nutrition.

Diagnóstico nutricional do cafeeiro por meio de análise floral e foliar

RESUMO: A análise química de flores tem sido estudada em algumas culturas. Para o cafeeiro, a análise do tecido floral possibilitaria a antecipação do diagnóstico nutricional das lavouras. O estudo objetivou (i) comparar a composição mineral de flores e de folhas de cafeeiros (ii) e gerar normas para diagnose nutricional do cafeeiro com base na análise de tecidos de flores e folhas das plantas. Para isso, foram avaliados os teores de nutrientes em flores e folhas e a produtividade de café em 26 lavouras comerciais na região de Manhuaçu, MG, durante três anos. As faixas criticas de nutrientes determinadas em flores são: 2,78 - 3,17; 0,23 - 0,28; 2,80 - 3,12; 0,30 - 0,37; 0,24 - 0,30; 0,15 0,18 dag kg-1 de N, P, K, Ca, Mg e S, e 17-21; 12 - 18; 52 - 80; 26-43 e 28-48 mg kg-1 para Zn, Cu, Mn, Fe e B, respectivamente. As faixas críticas de nutrientes em folhas foram: $2,63-2,86 ; 0,13-0,14 ; 2,13-2,33 ; 1,04-1,22 ; 0,27-0,33 ; 0,15-0,18$ dag $\mathrm{kg}^{-1} \mathrm{de} \mathrm{N}, \mathrm{P}, \mathrm{K}, \mathrm{Ca}$, Mg e S, e 9-14; 15 - 23; 80 - 115; 99 - 148 e 31 - $37 \mathrm{mg} \mathrm{kg}^{-1}$ para $\mathrm{Zn}$, Cu, Mn, Fe e B, respectivamente. A diagnose nutricional do cafeeiro, quanto aos nutrientes $\mathrm{N}, \mathrm{P}, \mathrm{Ca}, \mathrm{Fe}$, Cu e Mn, pode ser antecipada por meio da análise de flores.

Palavras-chave: Coffea arabica L., análise foliar, análise de flores, nutrição do cafeeiro.

\section{INTRODUCTION}

Leaf analysis is one of the principal tools to assess the nutritional status of agricultural and forest crops. If properly adopted, those analyses allow detecting deficiencies or excess of mineral nutrients in plants and supporting nutrient management programs based on soil analysis (DEUS et al., 2018; NOWAKI et al., 2017; RAGOZO et al., 2014).

A great effort has been made to properly adopt this type of analysis for coffee trees. A significant part of this effort is associated with studies aiming to define reference values for coffee tree diagnosis
(BARBOSA et al., 2006; FARNEZI et al., 2010; SILVA, et al., 2015). These standards must consider the portion of the tree to be analyzed, the sampling season, and the number of sub-samples to obtain a representative composite sample (MARTINEZ et al., 2004).

Flower mineral content assessment for plant nutritional diagnosis was proposed more recently than leaf analysis (SANZ et al., 1993). In Europe, more studies using this technique have been performed for fruit species like peach (IGARTUA et al., 2000; SANZ \& MONTAÑÉS, 1995), pear (SANZ et al., 1993), and orange trees (PESTANA et al., 2004). Few studies; however, have been conducted in Brazil. 
The advantage of flower analysis for coffee trees is anticipating the nutritional diagnosis when compared with leaf analysis (MARTINEZ et al 2003a), currently performed during the beginning of the fruit development. Thus, the flower analysis may be useful for adjusting the fertilization program at the beginning of the growing season, before irreversible productivity losses occur (MARTINEZ et al 2003a). However, it is still necessary to establish flower collection protocols for a nutritional diagnosis of coffee trees, in addition to a validation process under different farming conditions.

This study aimed to: (i) compare the mineral composition of coffee tree flowers and leaves, and (ii) design reference values for nutritional analyses of coffee trees, based on flower and leaf tissue analyses.

\section{MATERIALS AND METHODS}

\section{Defining the flower collection protocol}

This study was performed in the city of Manhuaçu, located in the Matas de Minas region (area of Brazilian Atlantic Forest in the east of Minas Gerais) at an average altitude of $750 \mathrm{~m}$. The soils of the region are predominantly Oxisols, the average rainfall is 1,466 $\mathrm{mm} / \mathrm{year}$, and the average temperature is $21.2{ }^{\circ} \mathrm{C}$.

In the first stage, this study compared the chemical composition of flowers located in different positions of adult trees plagiotropic branches. This procedure was performed to establish a flower collection protocol for nutritional analysis. A completely randomized experiment was conducted with the rosette position in plagiotropic branches composing the treatments. Complete flower rosettes were collected from the first to the sixth positions from the branch apex. The collection was performed using a zigzag pattern throughout an adult farm populated by 5,555 trees per hectare without dying lower branches, collecting flowers on all sides of cardinal exposure. Four repetitions were performed for each treatment. The obtained vegetable material was chemically analyzed to determine the concentration of macro and micronutrients.

Before the chemical analysis, the flowers were rinsed using deionized water, drought using a forced-air oven at $70{ }^{\circ} \mathrm{C}$ for 72 hours, and ground in a Wiley mill. The $\mathrm{N}$ content was determined after a sulfuric acid digestion using the Nessler colorimetric method (JACKSON, 1958). Subsequently, the material was submitted to nitric-perchloric acid digestion to determine $\mathrm{P}, \mathrm{K}, \mathrm{Ca}, \mathrm{Mg}, \mathrm{S}, \mathrm{Zn}, \mathrm{Cu}, \mathrm{Fe}$, and Mn contents (JOHNSON \& ULRICH, 1959) and dry ash digestion at $550^{\circ} \mathrm{C}$ for 3 hours to determine the $\mathrm{B}$ content (MALAVOLTA et al., 1997). The P content was measured by reducing phosphomolybdate using vitamin C (BRAGA \& DEFELIPO, 1974); the K content by flame emission spectrophotometry (MALAVOLTA et al., 1997); the $\mathrm{S}$ content by turbidimetry (JACKSON, 1958); and the $\mathrm{Ca}, \mathrm{Mg}, \mathrm{Zn}, \mathrm{Cu}, \mathrm{Fe}$, and Mn contents by atomic absorption spectrophotometry (AOAC, 1975). The $\mathrm{B}$ content was determined by the azomethine- $\mathrm{H}$ method (MALAVOLTA et al., 1997).

Data collection for comparing flowers and leaves analyses, and the elaboration of reference values for interpreting plant tissue analyses

In the second stage of this study, the nutrient content of flowers and leaves were compared, and reference values for a nutritional diagnosis based on flower analysis and the traditional method (leaf analysis) were established. Twenty-six commercial stands of Coffea arabica L. cv. Catuai at the productive stage were selected in different farms. The coffee stands were selected based on the coffee productivity history over three years, before collecting plant material.

Thirteen out of twenty-six stands were considered lowly productive with an average production below 30 bags ha $^{-1}$, and the other 13 as highly productive with an average production above $40 \mathrm{bags} \mathrm{ha}^{-1}$. The planting densities adopted in the farms ranged between 4 and 6 thousand plants ha ${ }^{-1}$. In each coffee stand, three lines containing ten plants were selected, and the flower and leaf samples of the five central plants were collected along with the 2005/2006, 2006/2007, and 2007/2008 harvests.

Flower samples were collected during the flowering stage, which coincided between late September and early October along the three years when this study was conducted; leaf samples were collected 60 days after flowering, during the early fruit development stage (green cherries stage). Flowers were collected from a complete floral rosette on the fourth node from the branch apex, from 20 branches per parcel located on the middle portion of both the free sides of the tree canopies. Leaf samples were collected from the fourth node from the branch apex (MALAVOLTA et al., 1997). Macro and micronutrient contents were determined at the second stage of this study through the same procedures of the first stage.

A manual harvest was performed when the fruits were at the harvest point (about 80 to $90 \%$ of fruits at the cherry stage) in the five selected plants from the parcel, to evaluate the production and estimate the productivity. The fruits were dried under the sunlight until constant humidity was reached $(13.5 \%)$, and the peels and grains were weighed to 
estimate productivity, expressed as bags of processed coffee per hectare.

\section{Data analysis}

The data obtained during the first stage to quantify nutrient content in flowers from different positions of the branch were compared using the F-test at $5 \%$ of significance. In the second stage, the data obtained each year in the more productive stands ( $\geq 40$ bags $^{-1}$ of processed coffee) were separated from those obtained less productive stands, composing populations with high and low productivity in which the average productivity was respectively 78.90 and 15.66 bags ha $^{-1}$. Subsequently, the confidence interval was calculated for the nutrient content of coffee tree flowers and leaves to compare highly and lowly productive farms, and among the years. Regression analyses were also performed to study the relationship between the nutrient contents of coffee flowers and leaves. All statistical analyses were performed through the «Genes» genetics and statistic application (CRUZ, 1997).

The critical ranges (CR) for nutrient contents in flowers and leaves were calculated using the equation $\mathrm{CR}=\mathrm{X} \pm(\mathrm{SX}) \mathrm{k}$, where $\mathrm{X}$ is the reference concentration of the nutrient in each analyzed part, obtained from the highly productive population, SX is the standard deviation of the mean, and $\mathrm{k}$ is a constant $(\mathrm{k}=1$ for nutrients with a coefficient of variation $\mathrm{CV}<20 \%, \mathrm{k}=0.8$ for nutrients with $20 \% \leq \mathrm{CV} \leq 40 \%$, and $\mathrm{k}=0.6$ for nutrients with a $\mathrm{CV}>40 \%$ to avoid wide ranges caused by the high coefficient of variation of some nutrients (MARTINEZ et al., 2003b).

\section{RESULTS AND DISCUSSION}

Nutrient content of flowers located in different positions of the coffee tree branch

There was no difference between macro and micronutrient contents in flowers from the first and sixth rosettes of coffee branches (Table 1); therefore, samples can be collected indistinctly for nutritional diagnosis purposes.

It is known that there may be an influence of the flower and leaf collection position on the nutrient content (AMARAL et al., 2002; LIMA et al., 2007). However, we were unable to find similar studies about the effect of the collection procedure on the nutritional diagnosis of coffee flowers. Based on this study, a higher stability of nutrient contents can be found in flower tissues when compared to leaves. In this sense, mistakes related to location of flower samples would present less influence on the coffee trees' nutritional diagnosis.

Farm productivity and the relationship between coffee flowers and leaves nutritional content

The statistical procedures (F-test and t-test) confirmed productivity differences among farms composing the highly and lowly productive groups of this study (Table 2 and Table 3). Furthermore, the reference population (highly productive farms)

Table 1 - Analysis of variance for macro and micronutrient contents in flowers collected from different positions of the coffee branches. Manhuaçu-MG, 2008.

\begin{tabular}{|c|c|c|c|c|c|c|c|}
\hline \multirow[t]{2}{*}{ Variation source } & \multirow[t]{2}{*}{ FD } & _ & & \multicolumn{4}{|c|}{ 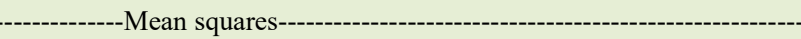 } \\
\hline & & $\mathrm{N}$ & $\mathrm{P}$ & $\mathrm{K}$ & $\mathrm{Ca}$ & $\mathrm{Mg}$ & $\mathrm{S}$ \\
\hline & & \multicolumn{6}{|c|}{ 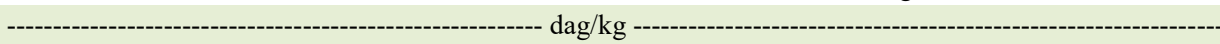 } \\
\hline Rosette Positon & 5 & $0.0015^{\mathrm{ns}}$ & $0.0001^{\mathrm{ns}}$ & $0.0156^{\mathrm{ns}}$ & $0.0016^{\text {ns }}$ & $0.0003^{\mathrm{ns}}$ & $4.4 \times 10^{-5 \mathrm{~ns}}$ \\
\hline Residual & 18 & 0.0657 & 0.0007 & 0.1621 & 0.0037 & 0.0009 & 0.0002 \\
\hline Mean & & 2.39 & 0.28 & 2.92 & 0.29 & 0.23 & 0.18 \\
\hline CV (\%) & & 10.74 & 9.23 & 13.79 & 20.86 & 12.77 & 7.73 \\
\hline \multirow{3}{*}{ Variation source } & \multirow{3}{*}{ GL } & \multicolumn{6}{|c|}{----------------------------------------------------------Mean Squares-------------------------------------------------------' } \\
\hline & & $\mathrm{Zn}$ & & & & $\mathrm{Mn}$ & B \\
\hline & & \multicolumn{6}{|c|}{--------------------------------------------------------------'mg/kg--------------------------------------------------------------' } \\
\hline Rosette Positon & 5 & $1.7033^{\mathrm{ns}}$ & & & $204^{\mathrm{ns}}$ & $10.0174^{\mathrm{ns}}$ & $28.9963^{\mathrm{ns}}$ \\
\hline Residual & 18 & 0.7834 & & & 8874 & 4.8638 & 10.8937 \\
\hline Mean & & 11.57 & & & & 26.85 & 31.26 \\
\hline $\mathrm{CV}(\%)$ & & 7.65 & & & 40 & 8.22 & 10.56 \\
\hline
\end{tabular}


Table 2 - Average productivity of processed coffee $(60 \mathrm{~kg}$ bags $/ \mathrm{ha})$ in samples from high and low productive coffee tree stands over three years.Manhuaçu-MG, 2008.

\begin{tabular}{|c|c|c|c|c|c|c|c|c|c|c|}
\hline \multirow[t]{2}{*}{ Farm identification } & \multicolumn{3}{|c|}{------High productive stands----- } & \multirow[t]{2}{*}{ Mean } & \multirow[t]{2}{*}{$\mathrm{CV}(\%)$} & \multicolumn{3}{|c|}{------Low productive stands------ } & \multirow[t]{2}{*}{ Mean } & \multirow[t]{2}{*}{$\mathrm{CV}(\%)$} \\
\hline & Year 1 & Year 2 & Year 3 & & & Year 1 & Year 2 & Year 3 & & \\
\hline 1 & 86.81 & 52.08 & 57.87 & 65.6 & 28.4 & 5.21 & 25.32 & 31.25 & 20.6 & 66.3 \\
\hline 2 & 104.17 & 61.55 & 81.02 & 82.2 & 25.9 & 3.47 & 23.15 & 28.41 & 18.3 & 71.7 \\
\hline 3 & 108.33 & 49.31 & 58.33 & 72.0 & 44.2 & 4.31 & 8.33 & 18.49 & 10.4 & 70.4 \\
\hline 4 & 132.58 & 57.87 & 85.23 & 91.9 & 41.1 & 8.29 & 7.10 & 23.15 & 12.8 & 69.6 \\
\hline 5 & 11.74 & 47.62 & 66.29 & 41.9 & 66.2 & 1.79 & 23.67 & 17.86 & 14.4 & 78.5 \\
\hline 6 & 89.29 & 77.52 & 47.62 & 71.5 & 30.1 & 2.91 & 8.93 & 9.69 & 7.2 & 51.8 \\
\hline 7 & 109.72 & 72.92 & 66.67 & 83.1 & 28.0 & 10.59 & 14.58 & 31.25 & 18.8 & 58.3 \\
\hline 8 & 86.35 & 52.08 & 88.18 & 75.5 & 26.9 & 10.07 & 7.72 & 20.83 & 12.9 & 54.3 \\
\hline 9 & 58.22 & 57.29 & 60.00 & 58.5 & 2.4 & 17.53 & 6.67 & 31.25 & 18.5 & 66.6 \\
\hline 10 & 118.30 & 58.33 & 98.04 & 91.6 & 33.3 & 5.00 & 19.61 & 25.00 & 16.5 & 62.6 \\
\hline 11 & 142.36 & 79.37 & 86.81 & 102.8 & 33.5 & 1.59 & 8.68 & 23.81 & 11.4 & 99.9 \\
\hline 12 & 83.33 & 60.92 & 58.33 & 67.5 & 20.4 & 7.31 & 12.50 & 36.55 & 18.8 & 83.0 \\
\hline 13 & 154.96 & 32.35 & 77.48 & 88.3 & 70.3 & 19.41 & 17.22 & 32.35 & 23.0 & 35.6 \\
\hline Média & 106.63 & 58.40 & 71.68 & 76.3 & 34.7 & 7.50 & 14.11 & 25.38 & 15.7 & 66.8 \\
\hline
\end{tabular}

$\mathrm{CV}=$ coefficient of variation

productivity was less biennial. The coefficient of variation of the harvests along the years was an average of $34.7 \%$ in highly productive farms compared with $66.8 \%$ in lowly productive farms. These results also indicated that the farms selected for the reference population were, in fact, nutritionally balanced once it is expected that better-nourished plants present a higher production stability over time (VALADARES et al., 2013).

The $\mathrm{N}, \mathrm{P}, \mathrm{Cu}, \mathrm{Fe}$, and $\mathrm{Mn}$ content in flowers varied similarly to the content in leaves (organ traditionally used for plant tissue analysis)

Table 3 - Pearson's correlation coefficient, regression equations, and coefficients of determination expressing the relationship between coffee flowers (x) and leaves (y) nutrient contents in high and low productive stands. Manhuaçu-MG, 2008.

\begin{tabular}{|c|c|c|c|c|c|c|}
\hline \multirow[t]{2}{*}{ Nutrients } & \multicolumn{3}{|c|}{-----------------High productive stands----------------- } & \multicolumn{3}{|c|}{ 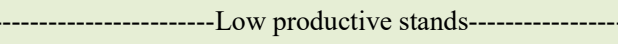 } \\
\hline & Coefficient & Equations & $\mathrm{R}^{2}$ & Coefficient & Equations & $\mathrm{R}^{2}$ \\
\hline $\mathrm{N}$ & $0.578^{*}$ & $y=1.70+0.35 x$ & 0.334 & 0.324 & & \\
\hline $\mathrm{P}$ & $0.707^{*}$ & $y=0.05+0.33 x$ & 0.500 & 0.255 & & \\
\hline $\mathrm{K}$ & -0.079 & & & 0.385 & & \\
\hline $\mathrm{Ca}$ & -0.039 & & & $0.611^{*}$ & $y=0.90+1.02 x$ & 0.373 \\
\hline $\mathrm{Mg}$ & 0.433 & & & 0.073 & & \\
\hline $\mathrm{S}$ & 0.200 & & & -0.160 & & \\
\hline $\mathrm{Zn}$ & 0.009 & & & 0.456 & & \\
\hline $\mathrm{Cu}$ & $0.574^{*}$ & $y=6.67+0.83 x$ & 0.330 & 0.437 & & \\
\hline $\mathrm{Fe}$ & $0.926^{*}$ & $y=37.87+0.91 x$ & 0.857 & $0.805^{*}$ & $y=52.19+0.55 x$ & 0.648 \\
\hline $\mathrm{Mn}$ & $0.715^{*}$ & $y=53.96+2.02 x$ & 0.511 & 0.510 & & \\
\hline $\mathrm{b}$ & 0.282 & & & 0.347 & & \\
\hline
\end{tabular}

*Significant values $(p<0.05)$.

Ciência Rural, v.51, n.7, 2021. 
collected 60 days after flowering, with higher correlations for $\mathrm{P}, \mathrm{Fe}$, and $\mathrm{Mn}$ (Table 3). In lowly productive farms, however, there was a direct and significant relationship for $\mathrm{Ca}$ and $\mathrm{Fe}$ only.

A similar behavior between nutrient contents in flowers and leaves was also observed in several studies about different crops (BELKHODJA et al., 1998; JIMÉNEZ et al., 2004; SANZ \& MONTAÑÉS, 1995) including coffee trees (MARTINEZ et al., 2003a).

Similarly to MARTINEZ et al. (2003a), who conducted a study under different management conditions, this study evidenced the possibility of using flowers to anticipate the diagnosis of deficiencies and excess of nutrients in coffee trees.

\section{Critical nutrient concentration ranges in coffee flowers and leaves}

The critical macro and micronutrient ranges for nutritional diagnose of coffee trees based on flowers and leaves analyses are presented in table 4. The critical ranges for interpreting flower tissue analyses obtained in this study were compared to those obtained by MARTINEZ et al. (2003b) in the city of Viçosa, MG, Brazil. In our study, the adequate values for $\mathrm{N}, \mathrm{K}, \mathrm{Ca}, \mathrm{Mg}, \mathrm{Zn}, \mathrm{Cu}$, and $\mathrm{B}$ were higher than those determined by MARTINEZ et al. (2003b) while similar for P, S, Fe, and Mn. An important aspect is that the average productivity used in this study was higher than in the farms studied by MARTINEZ et al. (2003b). The critical ranges for leaf analysis interpretation were also different from those defined for other regions (FARNEZI et al., 2009; MARTINEZ et al., 2003b). Those differences indicated that the reference values for plant tissue interpretation need to be regionalized as much as possible (MARTINEZ et al., 2003b), since the plant nutritional conditions change along with the farming environment.

\section{CONCLUSION}

Flowers between the first and sixth flower rosette from the branch apex can be indistinctly collected to diagnose the nutritional status of coffee trees.

Flower analysis is sensitive to the nutritional status of coffee trees and may stand as a complementary technique to diagnose using leaf analysis.

The nutritional diagnosis of coffee trees can be anticipated using flower analysis for N, P, $\mathrm{Ca}, \mathrm{Fe}, \mathrm{Cu}$, and $\mathrm{Mn}$.

Table 4 - Means, critical ranges (CR), coefficients of variation (CV, \%), and confidence interval (CI) for macro and micronutrient concentrations $\left(\mathrm{mg} \mathrm{kg}^{-1}\right)$ in coffee flowers and leaves in Manhuaçu, MG, Brazil, 2008.

\begin{tabular}{|c|c|c|c|c|c|c|c|c|}
\hline \multirow[t]{2}{*}{ Nutrients } & \multicolumn{4}{|c|}{--------------------------------Flowers------------------------------- } & \multicolumn{4}{|c|}{----------------------------------Leaves----------------------------' } \\
\hline & Mean value & CR & $\mathrm{CV}$ & $\mathrm{CI}$ & Mean value & $\mathrm{CR}$ & $\mathrm{CV}$ & $\mathrm{CI}$ \\
\hline $\mathrm{N}\left(\right.$ dag $\left.\mathrm{kg}^{-1}\right)$ & $2.98 \mathrm{a}$ & $2.78-3.17$ & 6.48 & $2.85-3.08$ & $2.74 \mathrm{~b}$ & $2.63-2.86$ & 4.28 & $2.66-2.81$ \\
\hline $\mathrm{P}\left(\right.$ dag $\left.\mathrm{kg}^{-1}\right)$ & $0.26 \mathrm{a}$ & $0.23-0.28$ & 9.21 & $0.24-0.27$ & $0.14 \mathrm{~b}$ & $0.13-0.14$ & 7.72 & $0.13-0.15$ \\
\hline $\mathrm{K}\left(\operatorname{dag~kg}{ }^{-1}\right)$ & $2.96 \mathrm{a}$ & $2.80-3.12$ & 5.36 & $2.85-3.05$ & $2.23 \mathrm{~b}$ & $2.13-2.33$ & 4.51 & $2.16-2.29$ \\
\hline $\mathrm{Ca}\left(\mathrm{dag} \mathrm{kg}^{-1}\right)$ & $0.33 \mathrm{~b}$ & $0.30-0.37$ & 13.51 & $0.30-0.36$ & $1.13 \mathrm{a}$ & $1.04-1.22$ & 8.23 & $1.07-1.18$ \\
\hline $\operatorname{Mg}\left(\right.$ dag kg $\left.{ }^{-1}\right)$ & $0.27 \mathrm{a}$ & $0.24-0.30$ & 12.40 & $0.25-0.30$ & $0.30 \mathrm{a}$ & $0.27-0.33$ & 9.20 & $0.28-0.31$ \\
\hline $\mathrm{S}\left(\right.$ dag $\left.\mathrm{kg}^{-1}\right)$ & $0.17 \mathrm{a}$ & $0.15-0.18$ & 9.79 & $0.15-0.18$ & $0.16 \mathrm{a}$ & $0.15-0.18$ & 9.40 & $0.15-0.18$ \\
\hline $\mathrm{Zn}\left(\mathrm{mg} \mathrm{kg}^{-1}\right)$ & $19 \mathrm{a}$ & $17-21$ & 12.04 & $18-21$ & $12 \mathrm{~b}$ & $9-14$ & 19.30 & $10-13$ \\
\hline $\mathrm{Cu}\left(\mathrm{mg} \mathrm{kg}^{-1}\right)$ & $15 \mathrm{a}$ & $12-18$ & 23.81 & $13-17$ & $19 \mathrm{a}$ & $15-23$ & 27.13 & $16-22$ \\
\hline $\operatorname{Mn}\left(\mathrm{mg} \mathrm{kg}^{-1}\right)$ & $66 \mathrm{~b}$ & $52-80$ & 26.94 & $55-77$ & $98 \mathrm{a}$ & $80-115$ & 17.84 & $86-108$ \\
\hline $\mathrm{Fe}\left(\mathrm{mg} \mathrm{kg}^{-1}\right)$ & $34 \mathrm{~b}$ & $26-43$ & 31.85 & $27-40$ & $123 \mathrm{a}$ & $99-148$ & 25.05 & $103-141$ \\
\hline $\mathrm{B}\left(\mathrm{mg} \mathrm{kg}^{-1}\right)$ & $33 a$ & $28-48$ & 16.42 & $29-36$ & $34 \mathrm{a}$ & $31-37$ & 8.48 & $33-36$ \\
\hline
\end{tabular}

Means followed by the same letter in the row do not differ by the $t$ test at $5 \%$ probability level. 


\section{ACKNOWLEDGEMENTS}

This study was financed in part by the Coordenação de Aperfeiçoamento de Pessoal de Nível Superior - Brasil (CAPES) - Finance Code 001"

\section{DECLARATION OF CONFLICT OF INTEREST}

The authors declare no conflict of interest. The founding sponsors had no role in the design of the study; in the collection, analyses, or interpretation of data; in the writing of the manuscript, and in the decision to publish the results.

\section{AUTHORS' CONTRIBUTIONS}

AVZ planned the research, collected data, performed statistical analyses and prepared the draft of the manuscript. HEPM supervised and coordinated the research, evaluated and discussed the results and revised the manuscript. JCLN cooriented the research and provided guidance for plant chemical analysis and statistical analysis. CDC cooriented the research and provided guidance for statistical analysis. SVV discussed results and revised the manuscript. All authors approved of the final version of the manuscript.

\section{REFERENCES}

AMARAL J. F. T. do, Bruckner CH, Herminia Emilia Prieto Martinez, et al (2002). Determination of leaf sampling techniques to assess the nutritional status of Barbados cherry, (Malpighia emarginata D.C.). Fruits 57:161-171. https://doi.org/10.1051/ fruits:2002015

AOAC - ASSOCIATION OF OFFICIAL ANALYTICAL CHEMISTS (1975) Official methods of analysis, 12th edn. AOAC, Washington.

BARBOSA D. H. S. G, et al. (2006). Nutritional analysis of coffee plantations for establishing "DRIS" standards for the Northwest region of the State of Rio de Janeiro, Brazil. Ciência Rural, v.36:1717-1722. Available from: <https://www.scielo.br/scielo. php? script $=$ sci arttext\&pid $=$ S0103-84782006000600008\&ln $\mathrm{g}=\mathrm{pt} \& \mathrm{t} \operatorname{lng}=\mathrm{pt}>$. Accessed: Jun. 21, 2020. doi: 10.1590/S010384782006000600008

BELKHODJA R., et al (1998). Iron deficiency in peach trees: Effects on leaf chlorophyll and nutrient concentrations in flowers and leaves. Plant and Soil, 203:257-268. Available from: $<$ https:// link.springer.com/article/10.1023/A:1004373202458>. Accessed: Jun. 21, 2019. doi: 10.1023/A:1004373202458.

BRAGA J. M. DEFELIPO B. M. (1974) Determinação espectrofotométrica de $\mathrm{P}$ em extratos de solo e material vegetal. Revista Ceres, v.21, n.113, p.73-85, 1974. Available from: $<$ https://www.bdpa.cnptia.embrapa.br/consulta/busca?b=ad\&id $=71859 \&$ biblioteca $=$ vazio \&busca $=$ autoria: $\% 22 \mathrm{M} \% 22 \&$ qFacets $=$ autoria: $\% 22 \mathrm{M} \% 22 \&$ sort $=\&$ paginacao $=$ t\&paginaAtual $=3369>$. Accessed: Jun. 21, 2019.

CRUZ C. D. (1997) Programa Genes: aplicativo computacional em genética e estatística. 442. Available from: $<$ http://arquivo.ufv. br/dbg/genes/genes Br.htm>. Accessed: Jun. 21, 2019.
DE DEUS J. A. L, et al. (2018) Balance design for robust foliar nutrient diagnosis of "Prata" banana (Musa spp.). Scientific Reports, 8:15040. Available from: <https://www.nature.com/ articles/s41598-018-32328-y>. Accessed: Jun. 21, 2019. doi: 10.1038/s41598-018-32328-y.

FARNEZI M. M DE M., SILVA E. DE B., GUIMARÃES P. T. G. (2009) Nutritional diagnosis of coffee plantations in the Upper Jequitinhonha Valley, Minas Gerais state, Brazil: DRIS norms and critical nutrient ranges. Rev Bras Ciência do Solo, v.33, n.4, 969978. Available from: $<$ https://www.scielo.br/scielo.php?script=sci arttext\&pid $=$ S0100-06832009000400021\&lng $=$ pt\&tlng $=$ pt $>$. Accessed: Jun. 21, 2019. doi: 10.1590/S0100-06832009000400021.

FARNEZI M. M. DE M., et al. (2010) Coffee beverage quality survey and evaluation of the nutritional state of coffee treee in the High Jequitinhonha, state of Minas Gerais, Brazil, using DRIS. Ciência e Agrotecnologia, v.34, n.5, p.1191-1198. Available from: $<$ https://www.scielo.br/scielo.php?script=sci_arttext\&pid=S141370542010000500016\&lng=pt\&tlng=pt $>$. Accessed: Jun. 21, 2019. doi: $10.1590 / \mathrm{S} 1413-70542010000500016$

IGARTUA E., et al. (2000) Prognosis of iron chlorosis from the mineral composition of owers in peach. The Journal of Horticultural Science and Biotechnology, v.75, p.111-118. Available from: <https://www.tandfonline.com/doi/ab s/10.1080/14620316.2000.11511209>. Accessed: Jun. 21, 2019. doi: $10.1080 / 14620316.2000 .11511209$.

JACKSON M. L. (1958). Soil chemical analysis. Prentice Hall, Inc., New Jersey, USA.

JIMÉNEZS., etal.(2004)FlowerandFoliarAnalysis for Prognosis of Sweet Cherry Nutrition: Influence of Different Rootstocks. Journal of Plant Nutrition, v.27, p.701-712. Available from: $\quad<$ https://www.tandfonline.com/doi/abs/10.1081/PLN120030376>. Accessed: Jun. 21, 2019. doi: 10.1081/PLN120030376 .

JOHNSON C., ULRICH A. (1959). Analytical methods for use in plant analysis, (Bulletin 766). University of California, Los Angeles.

LIMA R. DE L. S. DE, et al. (2007) Part of plant to sample leaves for nutritional status evaluation in soursop (Annona muricata L.). Ciência e Agrotecnologia, v.31, p.13201325. Available from: <https://www.scielo.br/scielo. php?script $=$ sci_arttext\&pid=S1413-70542007000500007\&lng $=\mathrm{pt} \& \operatorname{tng}=\mathrm{pt}>$. Accessed: Jun. 21, 2019. doi: 10.1590/S141370542007000500007.

MALAVOLTA E., VITTI G., OLIVEIRA S., (1997). Diagnóstico do estado nutricional de plantas: princípios e aplicações, 2ed. Potafos, Piracicaba.

MARTINEZ H. E. P., et al. (2003a) Faixas críticas de concentrações de nutrientes e avaliação do estado nutricional de cafeeiros em quatro regiões de Minas Gerais. Pesquisa Agropecuária Brasileira, v.38, p.703-713. Available from: <https:/www.scielo. br/scielo.php? script $=$ sci arttext\&pid $=$ S0100-204X2003000600 006\&lng=pt\&tlng=pt $>$. Accessed: Jun. 21, 2019. doi: 10.1590/ S0100-204X2003000600006.

MARTINEZ H. E. P., et al. (2004) Nutrição mineral, fertilidade do solo e produtividade do cafeeiro nas regiões de Patrocínio, Manhuaçu, Viçosa, São Sebastião do Paraíso e Guaxupé (Boletim técnico, 72). EPAMIG, Belo Horizonte. 
MARTINEZ H. E. P., et al. (2003b) Coffee-tree floral analysis as a mean of nutritional diagnosis. Journal of Plant Nutrition, v.26, p.1467-1482. Available from: $<$ https://www.tandfonline.com/doi/abs/10.1081/PLN-120021055>. Accessed: Jun. 21, 2019. doi: 10.1081/PLN-120021055.

NOWAKI R. H. D., et al. (2017) Phosphorus over-fertilization and nutrient misbalance of irrigated tomato crops in Brazil. Front. Plant. Sci., v.8, p.1-11. Available from: $<$ https://www.frontiersin. org/articles/10.3389/fpls.2017.00825/full>. Accessed: Jun. 21, 2019. doi: 10.3389/fpls.2017.00825.

PESTANA M., et al. (2004). Floral analysis as a tool to diagnose iron chlorosis in orange trees. Plant and Soil, v.259, p.287-295. Available from: <https://link.springer.com/article/10.1023\%2FB \%3APLSO.0000020979.83817.b4>. Accessed: Jun. 21, 2019. doi: 10.1023/B:PLSO.0000020979.83817.b4.

RAGOZO, C. R. A. et al. Nutritional balance and yield for green manure orange trees. Ciência Rural, 2014. v.44, n.4, p.616-621. Available from: $<$ http://www.scielo.br/scielo.php?script $=$ sci arttext\&pid=S0103-84782014000400007\&lng=en\&tlng=en $>$. Accessed: Jun. 21, 2019.
SANZ, M., et al. El estado nutricional del peral. Possibilidad del diagnóstico floral. Hortofruticultura, 1993. v.10, p.6062 .

SANZ, M.; MONTAÑÉS, L. Flower analysis as a new approach to diagnosing the nutritional status of the peach tree. Journal of Plant Nutrition, 21 ago. 1995. v.18, n.8, p.1667-1675. Available from: <http://www.tandfonline.com/ doi/abs/10.1080/01904169509365012>. Accessed: Jun. 21, 2019.

SILVA, R. A. et al. Nutritional diagnosis by Dris method of the cultivars. Cofee Science, 2015. v.10, n.2, p.204-213. Available from: <http://www.coffeescience.ufla.br/index.

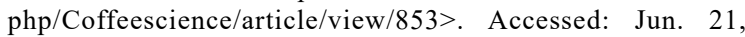
2019.

VALADARES, S. V. et al. Yield and production bienniality of dense coffee plantations under different levels of $\mathrm{N}$ and K. Pesquisa Agropecuaria Brasileira, 2013. v.48, n.3. Available from: $<$ https://www.scielo.br/scielo.php?script=sci abstract\&pid=S0100-204X2013000300008\&lng=pt\&nrm=iso\&t lng=en $>$. Jun. 21, 2019. 